\title{
Study and GIS-Based Mapping of Soil Chemical Properties in Kirkuk City, Iraq
}

\author{
Maryam Hassan Ahmed Sulyman ${ }^{1}$, Abbas Mohammed Noori ${ }^{2}$, Alyaa A. Al-Attar ${ }^{3}$ \\ \{ marynamh4@gmail.com ${ }^{1}$, abbasrsgis@gmail.com ${ }^{2}$, dr.alyaa@ntu.edu.iq ${ }^{3}$ \} \\ ${ }^{1}$ Department of Environment and Pollution Engineering, Technical College of Kirkuk, Northern \\ Technical University, Kirkuk 36001, Iraq \\ ${ }^{2,3}$ Department of Surveying Engineering, Technical College of Kirkuk, Northern Technical \\ University, Kirkuk 36001, Iraq
}

\begin{abstract}
The study included selecting seven sites in Kirkuk city to determine the soil chemical properties characteristics. The samples were collected and analyzed laboratory for the period from November 2016 and for three months at the rate of three samples per site. The main objective is to study the chemical properties of the soil of the selected areas. Also, the GIS technique has used to predict soil maps. However, soil chemical properties have analyzed for samples. The highest measurement concentrations of chemical properties ( $\mathrm{pH}$, Electrical conductivity, organic material, total soluble salts, gypsum, total carbonates, nitrates, chlorides and sulphates) were $(9,1695 \mu \mathrm{S} / \mathrm{cm}, 6.488 \%, 847.5 \%$, $3.57 \%, 6 \mathrm{mg} / \mathrm{l}, 1290 \mathrm{mg} / \mathrm{l}$ and $4.57 \mathrm{mg} / \mathrm{l})$ respectively. Furthermore, Inverse Distance Weighting (IDW) interpolation technique has used to produce geotechnical maps of the study area. The soil in the study area tends to be basal According to the chemical properties measurements.
\end{abstract}

Keywords: Soil, Chemical properties, GIS, Geotechnical maps, IDW

\section{Introduction}

The soil forms the outer envelope of the earth and consists of broken rocky materials that have previously been altered due to their exposure to environmental, biological and chemical criteria, including weather and erosion criteria. The soil varies from the basic components of its rock and it is due to the changes in the interaction between the four surfaces on the earth: the ground layer, the aquifer, the air and the biosphere [1]. The soil is a combination of soil organic components and minerals in liquid conditions (water) and gas (air) [2],[3]. Soil is containing materials include their porous granules and form the soil structure that fills those pores. Such pores contain water (liquid) and air (gas) [4]. The most common type of soil ranges between 1 and $2 \mathrm{~g} / \mathrm{cm} 3$ [5]. Soil is also called Earth, which comes from the world that we live on. Some components of the earth date from the pre-3rd geological era, but most of them do not date back to the pre-Pleistocene period (one of the latest and glacial periods) [6].

This life-sustaining layer is called a dynamically active, porous and well-constructed Pedosphere, efficiently distributing water, mass flows and energy. As well as the fact that the soil Sanda for life is working to filter a lot of industrial waste and pollutants and thus reduce the pollution of the environment, and called the science of soil science Pedology. A science that is the soil is different natural units and focuses on the development and physical relations, chemical and biological and dynamic nature and dynamic or rather is the science of soil study. 
Pedology science deals with the study of the soil as a source of the essence and structure of life [7].

There are many studies on the properties of the soil, like the study [8] in the area of Tuz where it was found that the percentage of soluble grains ranged between (22-99\%) and the proportion of sulphates between $(0.04-12.3)$. [9] studied some chemical properties of the soil for Mosul city and he found that the $\mathrm{pH}$ values range from (7.44 to 7.88). [10] studied the chemical properties of different regions of Switzerland. They found that organic matter ranged from (3.4 to 7.3\%). The National Center for Structural Laboratories, [11] has conducted soil investigations in the grain silo area in Kirkuk city. They found that gypsum content in the soil ranged between (67.4 and 0.09\%). The National Center for Structural Laboratories [12]. conducted soil investigations in Al-Shorja area in Kirkuk Governorate. Physical and chemical tests of soil and chemical analysis showed that the percentage of sulphates in the region ranged from (44.6-0.14\%). However, gypsum content ranging between $(95.44-0.3) \%$ and the percentage of carbonates ranged between $(42.0$ - 21.5\%). The National Center for Structural Laboratories [13] has conducted soil investigations of the residential complex in Corniche Street behind the Kirkuk Park. They have found that The percentage of sulphates in the region ranges between $(6.99-0.05 \%)$.

As a result of the rapid increase of construction work, soil mapping is an important issue in the region. Where Kirkuk city is one of the most important and vital cities of Iraq because of the containment of important natural resources such as oil and gas. In addition to the availability of fertile land and groundwater. Furthermore, to its geographical location. It is a link between central and northern Iraq. Soil properties could assist in the design process before the implementation of the construction works. The geotechnical properties of the soil play a large role in the prediction and thus avoid many of the engineering problems of the surface and deep foundations when constructing the building in a specific area [14]. It is necessary to identify the physical, mechanical, chemical and mineral properties of the soil, which are fundamental information in the geotechnical assessment process as well as the physical properties of soil classification for engineering purposes [15].

GIS is an efficient tool for spatial analysis and modelling [16]. The spatial distribution and variability are determined by geostatistical methods based on the spatial scale of the study region, the distance between samples and the model spatial pattern [17]. Interpolation methods are employed to estimate soil properties in areas without soil sample measurements. Inverse Distance Weighting (IDW) interpolation method widely used to predict soil properties map based on known samples. Spatial correlations of soil and mineral properties such as physical, chemical and biological properties were widely assessed and the Spatial Variability of Soil Properties was evaluated [18],[19].

Therefore, this study included some geotechnical tests for the soil in Kirkuk city. However, the main objective of this project is to study the chemical properties of the soil of the selected areas. Furthermore, preparing and predicting geotechnical spatial maps of the study area using IDW interpolation technique.

\section{Study area}

The study area is located within the city of Kirkuk between longitude (40'18 $\left.{ }^{\circ} 44\right)$ and $(00$ $\left.' 25^{\circ} 44\right)$ east and latitudes (30' $\left.22^{\circ} 35\right)$ and (00 $\left.38^{\circ} 35\right)$ north, which are (Shoreja, Ronaki, 
Arafa, Al-eamal alshaebi, Haziran, Aleaskari and Qadisiyah) [20]. Figure 1. shows the study area and location of samples.

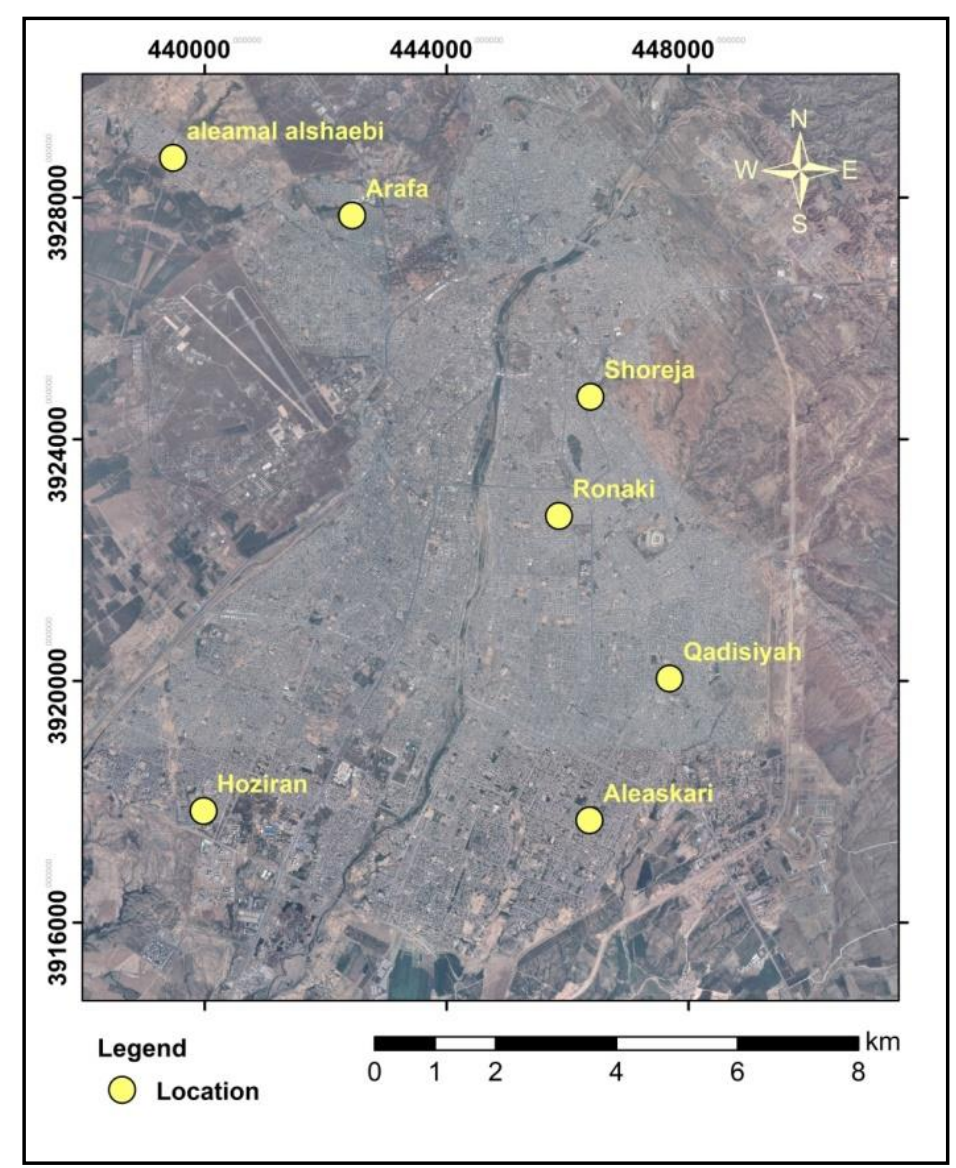

Fig. 1. The study area and samples location.

\section{Methodology}

It was conducted fieldwork in a period of one month to several sites of Kirkuk city. seven sites were identified for the purpose of collecting soil samples from some areas of Kirkuk. The samples covered the geographical areas which are (Shoreja, Ronaki, Arafa, Al-eamal alshaebi, Haziran, Aleaskari, and Qadisiyah). samples were collected from the surface of the soil in the depth of $(0-10 \mathrm{~cm})$. Furthermore, soil samples placed inside nylon bags accented by the names of areas and then transferred to the laboratory for the purpose of conducting chemical analyzes. coordinates of sites have taken using GPS. The study included analyzing soil chemical properties. 


\subsection{Laboratory work stage}

Laboratory work included testing of collected samples from the sites and applying Chemical analysis of soil. Table 1 show methods of Chemical examining of testing and analyzing for samples. In this study, nine soil chemical properties have studied which area $(\mathrm{pH}$, Electrical conductivity, organic material, total soluble salts, gypsum, total carbonates, nitrates, chlorides and sulphates)

Table 1. Methods of Chemical examining of testing and analyzing.

\begin{tabular}{lll}
\hline Characteristics & Method of measurement & Reference \\
\hline Hydrogen number $(\mathrm{pH})$ & device $(\mathrm{pH}$ meter) type $(\mathrm{Pw} 4 / 8 \mathrm{pm})$ & {$[21]$} \\
$\begin{array}{l}\text { Electrical Conductivity(EC) } \\
\mu \mathrm{S} / \mathrm{cm}\end{array}$ & $\begin{array}{l}\text { device E.C- Digital meter } \\
\text { instructions:WAG-WE30210 }\end{array}$ & {$[21]$} \\
Ratio Organic Material(O.M) & $\begin{array}{l}\text { Burn with oven and temperature (900) } \\
{ }^{\circ} \mathrm{C}\end{array}$ & {$[22]$} \\
Total Soluble Salts ratio & $\begin{array}{l}\text { Conductivity/TDS Digital meter } \\
\text { instructions: WAG-WE30210 }\end{array}$ & {$[21]$} \\
(T.D.S $)$ & $\begin{array}{l}\text { Deposition by acetone solution } \\
\text { Gypsum Content }\end{array}$ & {$[21]$} \\
& $\begin{array}{l}\text { Calibration with solution N0.01 } \mathrm{H}_{2} \mathrm{SO}_{4} \\
\text { to 4.5, 8.3 PH }\end{array}$ & {$[21]$} \\
Total carbonate $\left(\mathrm{HCO}^{3-}\right) \mathrm{mg} / 1$ & $\begin{array}{l}\text { Ultraviolet/visible Spectrophotometer } \\
\text { Silver nitrate Titration }\end{array}$ & {$[24]$} \\
Nitrates $\left(\mathrm{NO}_{3}\right) \mathrm{mg} / \mathrm{l}$ & Turbidity method & {$[21]$} \\
Sulfate $\mathrm{mg} / \mathrm{l}$ & & {$[15]$} \\
\hline
\end{tabular}

\subsection{Chemical properties}

pH is a measure of acidity and alkalinity of solutions, which represents the negative logarithm of the molecular concentration of hydrogen ion [25]. PH affects nutrient readiness, which in turn affects plant growth. The $\mathrm{pH}$ of the normal soil is between (4-10) [26]. High soil $\mathrm{pH}$ values are present in calcareous and basal soils, whereas low values exist in soils containing sulfuric acids [27],[28]. The lead element is less readily available because it is precipitated in the form of hydroxide, phosphate or leads carbonates. However, the heavy element of uptake is increased in the soils by decreasing $\mathrm{pH}$ and decreasing its height. $\mathrm{pH}$ values affected by many factors including installation and concentration of salts, carbonate ions and carbonate dissolved in water [29].

Electrical Conductivity (Ec). Soil salinity is one of the most widespread problems in the world because saline soils are characterized by the presence of high concentrations of mineral salts. It accumulates on the surface of the soil under droughts due to the evaporation process. The salinity is measured in the soil water extract in the form of electric conduction. Electric is located between (2-20) milli Siemens/ $\mathrm{cm}$ in water [30]. Soil salinity could produce either from weathering primary minerals in the earth's crust rocks or from other sources, such as 
groundwater when they are close to the earth's surface or through irrigation or transmitted to the soil by Wind and hurricane from saline areas [31].

Gypsum Content. Gypsum is calcium carbonate $\left(\mathrm{CaSO}_{4} \cdot 2 \mathrm{H}_{2} \mathrm{O}\right)$. A white or gray matter according to oxides that can be dissolved in groundwater if it is present in the soil. Gypsum is one of the most affected substances in the process of leaching Soluble. Separating Gypsum from the soil leading to the change of soil engineering properties. Gypsum ratio is hazardous to the soil if it exceeds $5.0 \%$ in soil [30]. The standard method for determining gypsum described using [21] method which involves sedimentation by acetone solution. Modifications of this method and other methods can be found in the Bulletin on Gypsum Soil [23].

Organic Material Ratio. Organic soil levels can vary by acidity depending on soil quality and climatic conditions such as heat and water dispersion. Soil organic content affects its constituent content Heavy metals [32]. Also, it affects the $\mathrm{pH}$ value, as their degradation results in organic acids that lead to a reduction in the $\mathrm{pH}$ value [9],[33]. The percentage of organic material is high if it is more than (1)\%, but the ratio (0.5)\% causes problems for soil strength [34]. Organic material dissolves in water. Organic acids lead to oxidation of organic carbon with reducing soil resistance [31]. Organic materials are derived from large types of animal and plant residues. However, many organic compounds have undesirable effects on the geological behaviour of soil [35].

Total Soluble salts ratio. Salinity ratio is the ratio of water-soluble salts to soil weight [35]. The solubility of the salts is different depending on their nature. In general, Chloride salts are the easiest solubility of carbonate and sulfate. The degree of solubility is affected by temperature, $\mathrm{pH}$ value, dissolved carbon dioxide $\left(\mathrm{CO}_{2}\right)$, evaporation and moisture. the negative effects of high and high concentrations of salts in soil solution. Increase the pressure osmosis and this reduces the ability of the plant to absorb water and salts from the soil. However, the occurrence of toxicity with some salts of plants growing in the soil. The presence and solubility of salts cause serious engineering problems as they affect the overall geotechnical properties of the different soil and the structure of the foundations. This test is important for estimating the salinity ratios found in the soil.

Chlorides. Chlorides are found in the soil in the form of different salts that are soluble in water. The presence of chlorides in dry soils is frequent and therefore can be estimated in water abstractions and its concentration in the soil varies according to soil quality and salinity. $(0.02 \%)$ is the critical limit of chlorides in the soil for plant growth. The chlorine salts are highly soluble in water and have an effect on the properties of the soil.

Sulphate. Soluble sulphate in water is usually found in soil in the form of sodium sulphate and magnesium sulphate. Calcium sulphate is found in the form of gypsum, but it is slow to dissolve in water. The ratio of sulphates found in soil is usually expressed by finding the ratio of sulfur oxides. The presence of sulphates in the soil at high rates leads to problems such as attacking cement, which leads to complex compounds with it. This crystallization process is accompanied by an increase in the size of the concrete resulting in the destruction of the concrete blocks [36]. 


\subsection{Inverse distance weighting (IDW)}

Inverse distance weighted (IDW) is held as one of the most common techniques for interpolating. It is used to forecast values for any unmet location by calculating the expected position of the surrounding values. It is an interpolating type of deterministic process with a known distributed collection of samples. The values assigned to unknown samples are determined by the weighted average of the identified points available [37].

\section{Result and Discussion}

Different soil maps of chemical properties were mapped in the town of Kirkuk and the interpolation using IDW was achieved to predict the expansion of soil properties in the town. Nine soil properties in the city have been analyzed according to the distribution of the test samples which are $\mathrm{pH}$, Electrical conductivity, organic material, total soluble salts, gypsum, total carbonates, nitrates, chlorides and sulphates (Tables 2). The raster pattern of soil characteristics has been graded in nine groups according to IDW.

Table 2. Chemical properties of samples.

\begin{tabular}{cccccccccc}
\hline Locations & PH & EC & $\begin{array}{c}\text { O.C.M } \\
(\%)\end{array}$ & $\begin{array}{c}\text { T.D.S } \\
(\%)\end{array}$ & $\begin{array}{c}\text { Gypsum } \\
(\%)\end{array}$ & Carbonates & Nitrate & Chloride & Sulfate \\
\hline Shoreja & 8.4 & 325 & 4.486 & 162.5 & 0.356 & 3 & 9.6 & 850 & 4.57 \\
Ronaki & 7.8 & 1695 & 4.798 & 847.5 & 3.577 & 2.4 & 10.4 & 530 & 3.6 \\
Arafa & 9 & 158.6 & 6.488 & 79.3 & 0.756 & 4 & 10.4 & 815 & 2.63 \\
aleamal & 8.3 & 600 & 4.743 & 300 & 0.381 & 2.8 & 8 & 590 & 2.45 \\
alshaebi & & & & & & & & & \\
Haziran & 8.6 & 312 & 5.234 & 156 & 0.499 & 2 & 6.16 & 910 & 2.5 \\
Aleaskari & 8.3 & 782 & 2.703 & 391 & 1.0438 & 3.5 & 11.92 & 670 & 2.05 \\
Qadisiyah & 8.8 & 88.7 & 6.157 & 44.3 & 0.553 & 6 & 12 & 1290 & 2.3 \\
\hline
\end{tabular}

\subsection{Acid function( $\mathrm{pH})$}

The results are shown in Figur 2 (a) and (b) indicate that the $\mathrm{pH}$ values of soil samples taken from some region of Kirkuk in-depth $(0-10 \mathrm{~cm})$ ranged between (7-9). In comparison with other studies, it has found that the results of our study are higher than the results of the $\mathrm{pH}$ obtained in 2001 for the soil of Mosul city which ranged between (7.44-7.88) [9]. The results of the present study are higher than those obtained from the soil of Baghdad where values ranged (6.9 - 8.20) respectively, due to the fact that Baghdad is a large city with a high population and traffic density, where emissions increase the $\mathrm{pH}$ of the soil. 


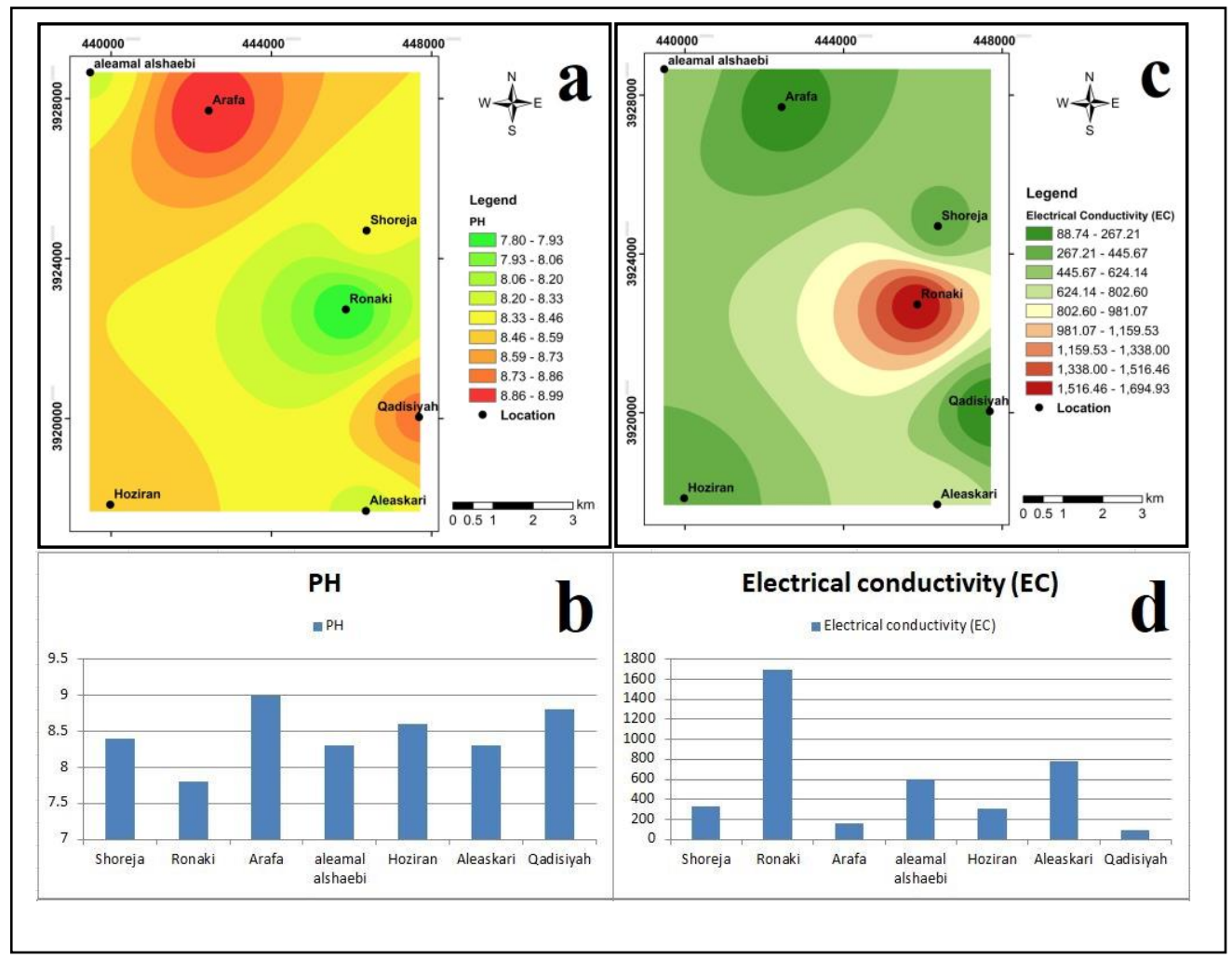

Fig. 2. (a) Prediction map of $\mathrm{pH}$ using IDW interpolation method, (b) $\mathrm{pH}$ chart of samples, (c) Prediction map of Electrical conductivity (E.C) using IDW interpolation method, (D) Electrical conductivity chart of samples.

\subsection{Electrical conductivity (EC)}

The results indicate that the values of the electrical conductivity of soil samples taken from some regions of Kirkuk ranging from $(88.7-1695 \mu \mathrm{S} / \mathrm{cm})$ (Figure 2 (c) and (d)). Comparing the results of the current study with previous studies, the results of the current study are less than the results obtained by [8] of Al-Tawz district which ranged from $(115.8-1938 \mu \mathrm{S} / \mathrm{cm})$. However, the results showed an increase in the values of electrical conductivity due to increased ratios of gypsum salts or calcium hydroxide. It was found that the results of the present study are higher than the results obtained by [9] for the soil of Mosul city. So, the highest value of electrical conductivity was $1575 \mu \mathrm{S} / \mathrm{cm}$.

\subsection{Organic Material Ratio}

The highest percentage of organic material have shown in the Arafa area which was $6.488 \%$. While, the lowest percentage was found in Aleaskari area and which was $2.703 \%$ 
(Figure 3 (a) and (b)). The results of our study were less than the results of [9] of Mosul city which ranged between $6.58-16.95 \%$. In contrast, our results were less than the results of the [10] where they studied different regions of Switzerland. However, the role of microorganisms such as bacteria, phosphates, primates and du Insects play an important role in the decomposition of organic matter [38].

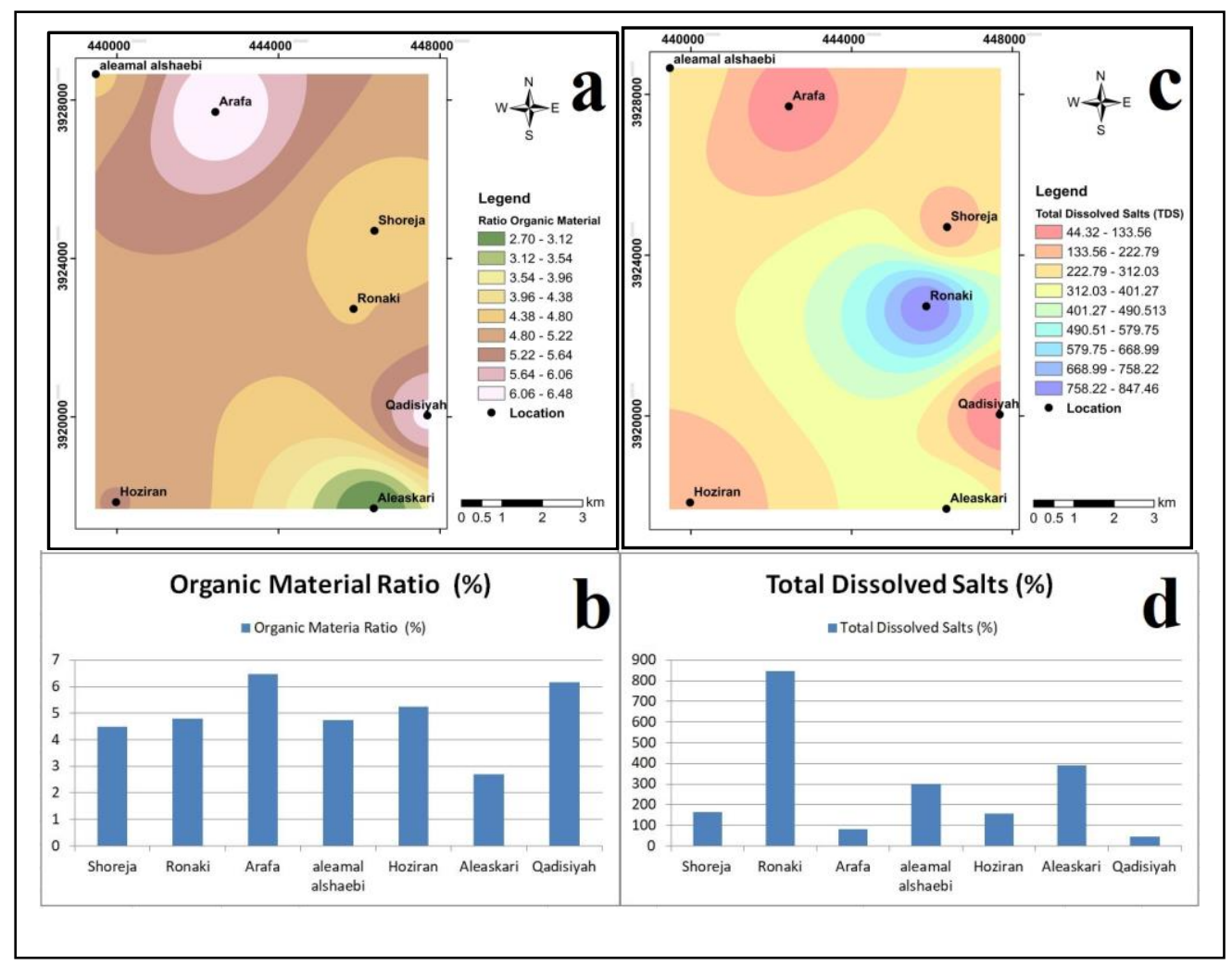

Fig. 3. (a) Prediction map of Organic Material Ratio using IDW interpolation method, (b) Organic Material Ratio chart of samples, (c) Prediction map of Total Dissolved Salts (T.D.S) using IDW interpolation method, (D) Total Dissolved Salts (T.D.S) chart of samples.

\subsection{Total Dissolved Salts (T.D.S)}

The results of T.D.S shown in Figure 3 (c) and (d) and it is indicated that the lowest percentage was found in Qadisiyah area which was $44.3 \%$. While, the highest percentage was found in Ronaki area (847.5\%) and the values ranged between (44.3-847.5\%). Our results are higher than the results by [39] of the Babylon city where the percentage of soluble salts ranging between $(0.1-26.28 \%)$. Therefore, the results significantly exceeded the percentage determined by [34] of $0.5 \%$. The saline content in the Middle East soils is determined by sulphate, chlorides, calcium carbonate, sodium and magnesium [40]. 


\subsection{Gypsum ratio}

The results of the study shown in Figure 4 (a) and (b) and it is shown that the highest percentage of gypsum or $\mathrm{CaSO}_{4} \cdot 2 \mathrm{H}_{2} \mathrm{O}$ was found in Ronaki regions of $3.577 \%$. On the other hand, The lowest percentage was $0.356 \%$. The results indicate that all samples have a small gypsum ratio. This little ratio of gypsum is a result of washing sediment composition by the Khasa river in Kirkuk city of or by rain [7]. When comparing the current study with previous studies, the National Center for Structural Laboratories [11] conducted soil investigations in the southern Saylo area of Kirkuk. The results of the tests revealed that the gypsum content in the soil was between (0.09-67.4\%).

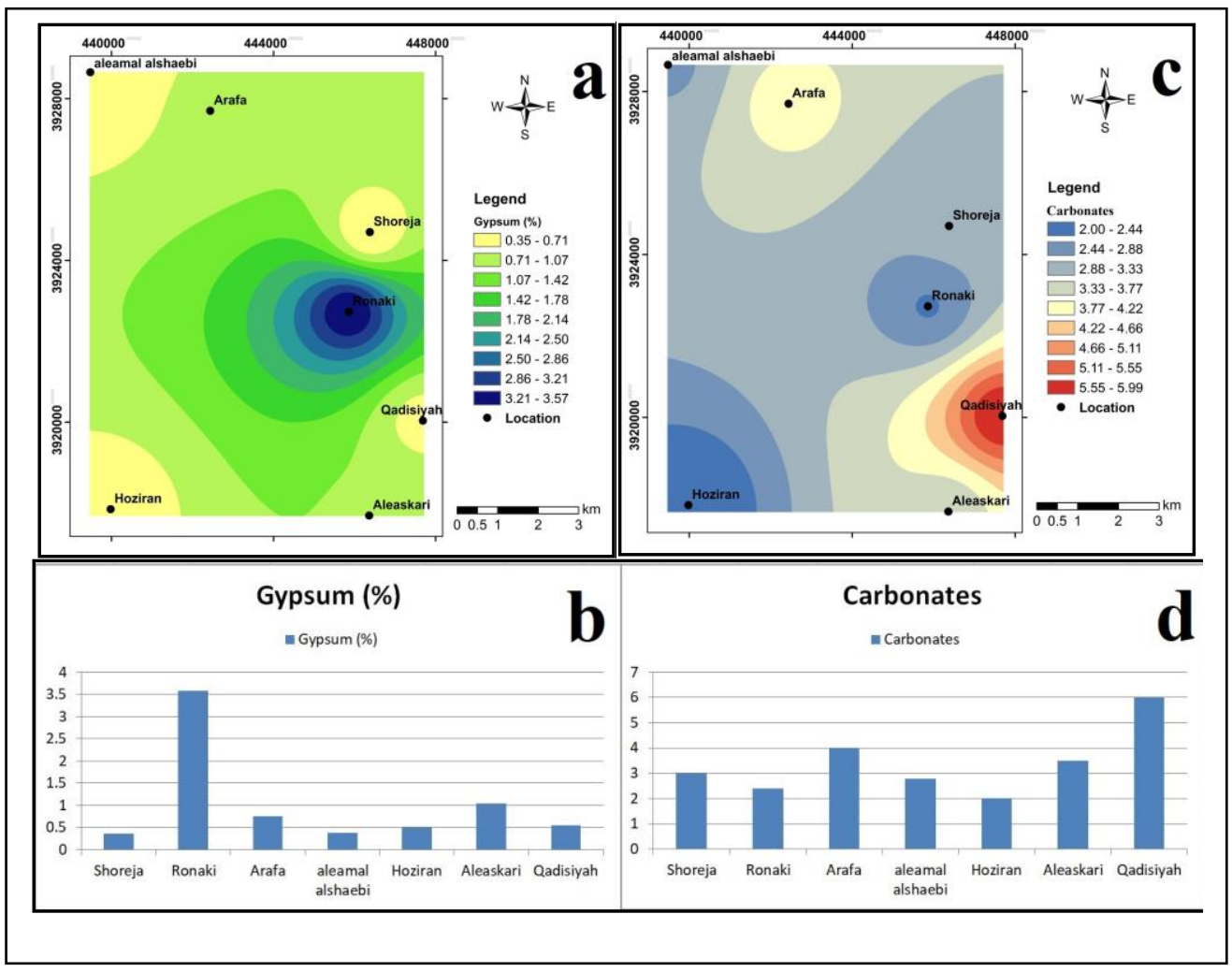

Fig. 4. (a) Prediction map of Gypsum ratio using IDW interpolation method, (b) Gypsum ratio chart of samples, (c) Prediction map of Carbonates using IDW interpolation method, (D) Carbonates chart of samples. 


\subsection{Carbonates}

The highest concentration of total carbonates for soil samples was found in Qadisiyah area where it was $(6 \mathrm{mg} / \mathrm{L})$ while the lowest value was recorded in the Hoziran $(2 \mathrm{mg} / \mathrm{L})$ area as shown in Figure 4 (c) and (d). When comparing these values with the previous study [8] for Tuz district where it ranged between $(27.7-10741 \mathrm{mg} / \mathrm{L})$.

\subsection{Nitrate}

The highest concentration of nitrates was found in Al Qadisiyah and Al-Askari areas. Concentrations $(12$ - 11.92) $\mathrm{mg} / \mathrm{L}$ respectively for soil samples taken from some regions of Kirkuk at depth $(10 \mathrm{~cm})$ as shown in Figure 5 (a) and (b). The high concentration of nitrates in these two regions is due to the increase in nitrogen oxides $\left(\mathrm{NO}\right.$ and $\left.\mathrm{NO}_{2}\right)$ emissions from vehicle fuel combustion due to heavy traffic in the Qadisiyah and Al-Askari area, with heavy vehicular traffic. When comparing our results with the study of [8] it is found that the concentrations of nitrates in the soil of Tuz ranging between (16.45 - 16.21).

\subsection{Chlorides}

The concentration of chlorides ranged between (530-1290 mg / L) (Figure 5 (c) and (d)). Where the highest value was recorded in the area of Qadisiyah and the lowest value in the area of Ronaki which are $(0.265-0.645 \%)$ respectively. [33] studied soil in Kirkuk and he is found that the chlorides ranged between (0.03-0.09\%). However, oxides affected the geotechnical properties of the soil. In general, chloride salts have great solubility in water.

\subsection{Sulfate content}

The results have shown in Figure 6 (a) and (b) and indicate that most of the soil in the studied sites contains low sulfur content with the exception of some areas in the middle of the study area (Ronaki, Shoreja). The highest value was recorded in Shoreja area $(4.57 \mathrm{mg} / \mathrm{L})$, and the lowest value was recorded in Al-Askari area $(2.05 \mathrm{mg} / \mathrm{L})$. When compared with previous studies, The [39] study of Babylonian soil recorded values of measured sulphates ranging from (0.04-12.3 \%). The National Center for Structural Laboratories [12] conducted soil investigations in the area of Al-Shorja in Kirkuk governorate. Chemical analysis shows that the sulphate percentage in the region ranges from $(0.14-44.6 \%)$. 


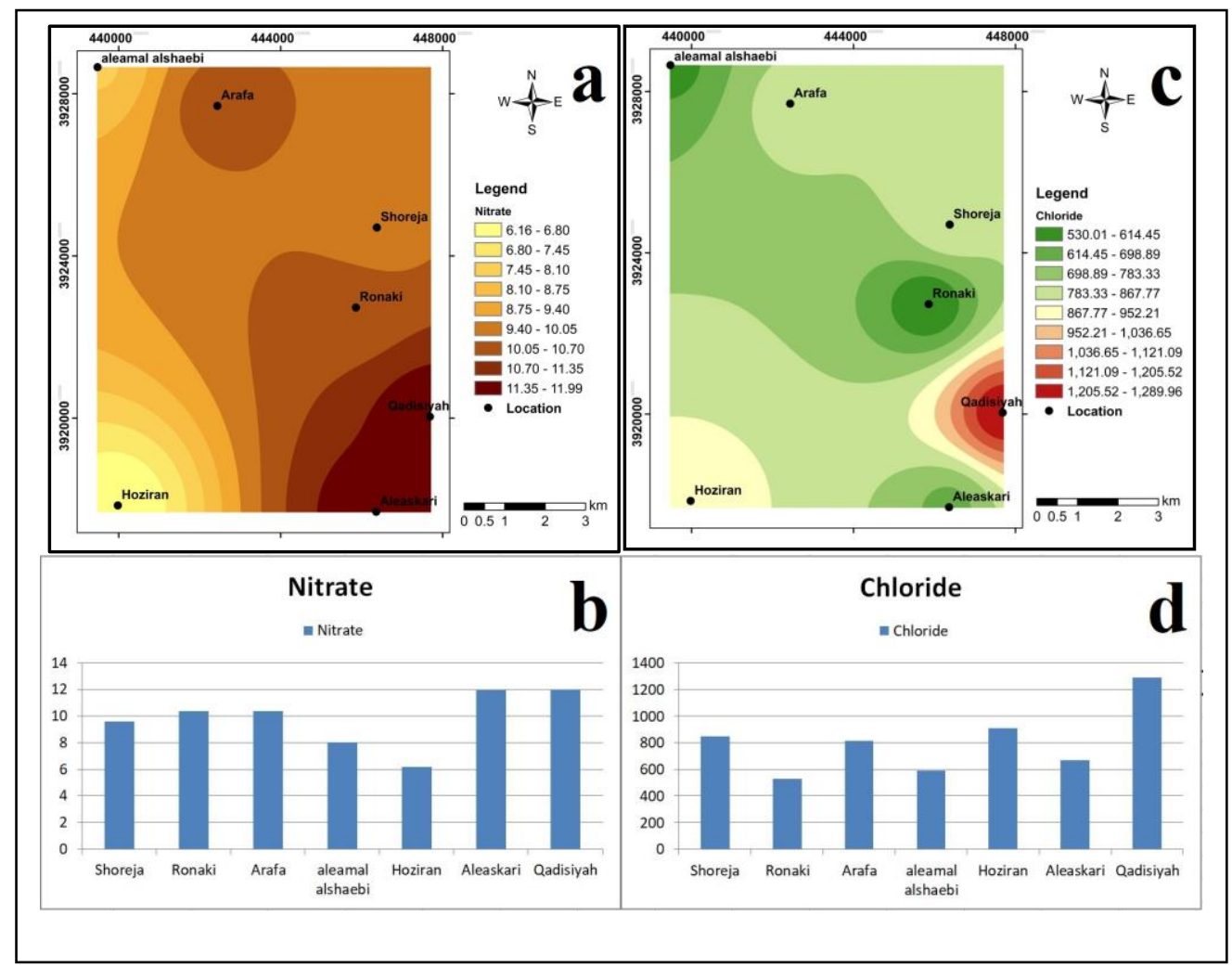

Fig. 5. (a) Prediction map of Nitrate using IDW interpolation method, (b) Nitrate chart of samples, (c) Prediction map of Chloride using IDW interpolation method, (D) Chloride chart of samples.

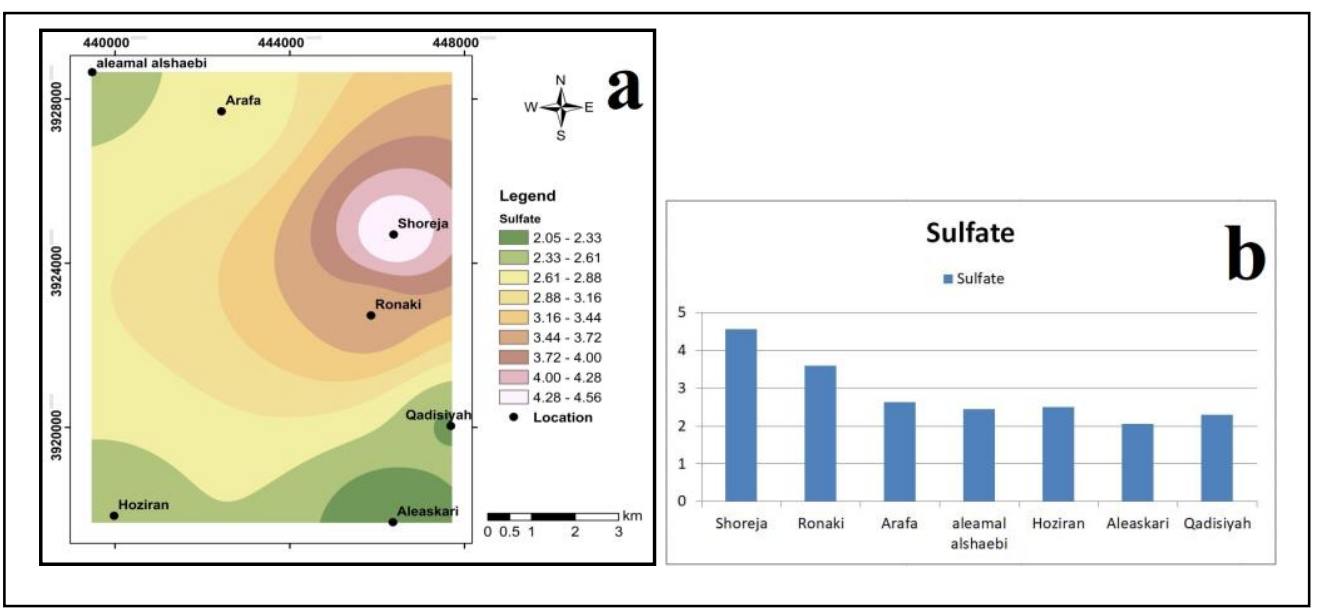

Fig. 6. (a) Prediction map of Sulfate content using IDW interpolation method, (b) Sulfate content chart of samples. 


\section{Conclusion}

Soil samples have been obtained in-depth $(0-10 \mathrm{~cm})$ from the top of the soil surface. Chemical tests showed high $\mathrm{pH}$ values, which range between $(7.8-9)$. Therefore, the soil in the study area can be classified as alkaline soils. The higher the $(\mathrm{pH})$, the higher the soil base, and the less gypsum with calcium carbonate dissolve. The outcome values of electrical conductivity range between $(88.7-1695 \mu \mathrm{S} / \mathrm{cm})$ due to its high salinity levels and due to the presence of high concentrations of salt minerals. The study showed that there is a high percentage of soluble salts which ranged between $(44.3-847.5 \%)$. The study area soil is classified as saline so that it reduces resistance to stresses on the soil. Gypsum ranges between (0.356-3.577\%) and has an impact on the properties of the soil as gypsum has a high solubility in water. Organic matter ranges from $(2.703-6.488 \%)$. However, the study indicates that the values are more than (1)\%, so the ratio has undesirable effects on the geological behaviour of soil. So, it can to say that organic materials have a significant negative impact on the soil. through their effect on the compressive properties of the soil and their effect on direct shear and increased pores in the soil. The results of the study show that most of the soil in the studied sites contains low sulfur content. GIS techniques are found to be best suited for the quantification of the soils chemical properties and its modelling in the study area. IDW Interpolation helpful for the soil management, practices and treatments used to protect soil and enhance its performance.

\section{References}

[1] Chesworth, W. (Ed.). (2007). Encyclopedia of soil science. Springer Science \& Business Media.

[2] Voroney, R. P. (2007). The soil habitat. In Soil microbiology, ecology and biochemistry (pp. 2549). Academic Press.

[3] Danoff-Burg, J. A. (2000). The Terrestrial influence: Geology and soils. Earth Institute Center for Environmental Sustainability.

[4] Taylor, S. A., \& Ashcroft, G. L. (1972). Physical edaphology. The physics of irrigated and nonirrigated soils.

[5] Shiri, J., Keshavarzi, A., Kisi, O., Karimi, S., \& Iturraran-Viveros, U. (2017). Modeling soil bulk density through a complete data scanning procedure: Heuristic alternatives. Journal of Hydrology, 549, 592-602.

[6] Ojiako, E. N., \& Okonkwo, M. N. (2013). Analysis of heavy metals in soil of mechanic workshop in Onitsha metropolis. Advances in Applied Science Research, 4(1), 79-81.

[7] Majid, Nazim Necmettin, (2004) "Study of geotechnical properties of gypsum in selected sites of the city of Kirkuk". doctoral dissertation, Faculty of Science, University of Baghdad, (188) pages.

[8] Mohammed, Sheno Mustafa Ali, 2008 "The study of the quality of rainwater and its impact on some soil characteristics in the district of Al-Tuz", Master Thesis, Faculty of Engineering, University of Tikrit.

[9] Hayali, Afaf Khalil Abdullah, (2001)"an environmental study of some pollutants in the city of Mosul," Master, Faculty of Science, Mosul University.

[10] Tandy, S., Bossart, K., Mueller, R., Ritschel, J., Hauser, L., Schulin, R., \& Nowack, B. (2004). Extraction of heavy metals from soils using biodegradable chelating agents. Environmental Science \& Technology, 38(3), 937-944.

[11] NCCL, (2001 a-d), soil investigation for Kirkuk New grain soil (report no. (1/1/8) part 1 , Baghdad.

[12] NCCL,(1992b),Tourist Hotel in Tikreet,Report No.144. 
[13] NCCL, (2001c), soil investigation for Housing Complex at Kirkuk(Korneesh street), Report No (1/1/ 68) Baghdad.

[14] A. M. Noori, B. Pradhan, and Q. M. Ajaj, "Dam site suitability assessment at the Greater Zab River in northern Iraq using remote sensing data and GIS,” J. Hydrol., 2019.

[15] Verma, B. C., Swaminathan, K., \& Sud, K. C. (1977). An improved turbidimetric procedure for the determination of sulphate in plants and soils. Talanta, 24(1), 49-50.

[16] A. M. Noori, W. M. Qader, F. G. Saed, and Z. A. Hamdany, "Quantification of Morphometric Parameters to Analyze the Watershed Characteristics: A Case Study of Rosti Watershed, Iraq," International Journal of Advanced Science and Technology, vol. 28, no. 13, pp. 273-289, 2019.

[17] Shit, Pravat Kumar, Gouri Sankar Bhunia, and Ramkrishna Maiti. "Spatial analysis of soil properties using GIS based geostatistics models." Modeling Earth Systems and Environment 2, no. 2 (2016): 107.

[18] Zhao, Wenju, Taohong Cao, Zongli Li, and Jie Sheng. "Comparison of IDW, cokriging and ARMA for predicting spatiotemporal variability of soil salinity in a gravel-sand mulched jujube orchard." Environmental monitoring and assessment 191, no. 6 (2019): 376.

[19] Duan, Liangxia, Zhenwei Li, Hongxia Xie, Zhiming Li, Liang Zhang, and Qing Zhou. "Largescale spatial variability of eight soil chemical properties within paddy fields." CATENA 188 (2020): 104350 .

[20] Shareef, M. A., Hassan, N. D., Hasan, S. F., \& Noori, A. M. "Integrating of GIS and fuzzy multicriteria method to evaluate land degradation and their impact on the urban growth of Kirkuk city, Iraq". International Journal of Advanced Science and Technology 28, no. 15 (2019): 88-815.

[21] Richards, L. A. comp. 1969. Diagnosis and improvement of saline and alkali soils. Agric. Handb, 60.

[22] Hesse, P. R. (1971). A Textbook of Soil Chemical Analysis, Chemical Pub. Co., New York.

[23] FAO,1990,Management of gypsiferous soils, Soils Bull, No. 62, Food and Organization, Rome, Italy.

[24] Abawi, Suad Abdel-Hassan, Mohammed Suleiman, "Environmental Engineering for Water Testing", Dar Al-Hikma for Printing and Publishing, Mosul, (1990).

[25] Krauskop f, K.B., (1985), Introduction to Gechemistry, My Graw- Hill. Lambe, T.W., 1951, Soil Testing For Engineers, John Wiley.

[26] Al-Abbas, F. A., \& Jinnah, F. R. (2019). Effect of spraying with moringa leaves extract and the soaking solution of fenugreek seeds and zinc in the traits of root growth and chemical traits for the gerbera plants (Gerbera Jamesonii). Plant Archives, 19(2), 1247-1258.

[27] McKeague, J. A., McKeague, J. A., \& Wang, C. (1978). Manual on soil sampling and methods of analysis.

[28] McLean, E. O. (1983). Soil pH and lime requirement. Methods of soil analysis: Part 2 Chemical and microbiological properties, 9, 199-224.

[29] Collins, A. (1975). Geochemistry of oilfield waters. Elsevier.

[30] Arutyunyan, R. N., \& Manukyan, A. V. (1982). Prevention of piping deformations in gypseous soils in Erevan. Soil Mechanics and Foundation Engineering, 19(4), 151-154.

[31] Hendry, M. J., Lawrence, J. R., Zanyk, B. N., \& Kirkland, R. (1993). Microbial production of CO2 in unsaturated geologic media in a mesoscale model. Water Resources Research, 29(4), 973-984.

[32] Buée, M., Courty, P. E., Mignot, D., \& Garbaye, J. (2007). Soil niche effect on species diversity and catabolic activities in an ectomycorrhizal fungal community. Soil Biology and Biochemistry, 39(8), 1947-1955.

[33] Qadir, Manal Samir (2015): Study of some geotechnical properties in selected locations of Kirkuk city, Unpublished Master Thesis .Tikrit University, Iraq.

[34] Baver, L. D., Gardner, W. H., \& Gardner, W. R. (1972). Soil physics (No. 04; S592. 3, B38 1972.). New York: Wiley. 
[35] Shaykhil, Naznaz, Farid, Abdul-Ahad, Thomas, Nawal (1999): National Center for Structural Laboratories, Program for the development of the adequacy of performance, chemistry book (3), 101 p.

[36] Zhang, Z., Jin, X., \& Luo, W. (2019). Long-term behaviors of concrete under low-concentration sulfate attack subjected to natural variation of environmental climate conditions. Cement and Concrete Research, 116, 217-230.

[37] Ajaj, Q. M., Shareef, M. A., Hassan, N. D., Hasan, S. F., \& Noori, A. M. (2018). GIS based spatial modeling to mapping and estimation relative risk of different diseases using inverse distance weighting (IDW) interpolation algorithm and evidential belief function (EBF)(Case study: Minor Part of Kirkuk City, Iraq). Int. J. Eng. Technol.

[38] Holík, L., Hlisnikovský, L., Honzík, R., Trögl, J., Burdová, H., \& Popelka, J. (2019). Soil Microbial Communities and Enzyme Activities after Long-Term Application of Inorganic and Organic Fertilizers at Different Depths of the Soil Profile. Sustainability, 11(12), 3251.

[39] Jubouri, Hamid Hassan (2002): Preliminary Geotechnical Maps of Soil in Babil Governorate and Some Neighboring Areas, Unpublished Master Thesis, Baghdad University, Faculty of Science, 168 p. [40] Liu, Y., Wang, Q., Liu, S., ShangGuan, Y., Fu, H., Ma, B., ... \& Yuan, X. (2019). Experimental investigation of the geotechnical properties and microstructure of lime-stabilized saline soils under freeze-thaw cycling. Cold Regions Science and Technology, 161, 32-42. 